\title{
NITROGEN LEACHING LOSSES ON A VOLCANIC ASH SOIL AS AFFECTED BY THE SOURCE OF FERTILISER
}

\author{
Marta Alfaro V. ${ }^{\text {; }}$ Francisco Salazar S. ${ }^{\text {; }}$ Denisse Endress B. ${ }^{2}$; Juan C. Dumont L. ${ }^{1}$; \\ Aldo Valdebenito B. ${ }^{1}$ \\ ${ }^{1}$ Instituto de Investigaciones Agropecuarias, INIA, Remehue P.O. Box 24-O Osorno \\ Chile. Corresponding author. Phone: +56 64233515. \\ Fax: +56 64 237746. Correo electrónico: malfaro@inia.cl. \\ ${ }^{2}$ Universidad de Los Lagos. Postgraduates School. P.O. Box 933 Osorno, Chile.
}

\section{Pérdidas de nitrógeno por lixiviación por efecto de la fuente del fertilizante en un suelo derivado de cenizas volcánicas}

Keywords: fish sludge, dairy slurry, inorganic fertilizer, water quality

\begin{abstract}
An intact lysimeters study was carried out to measure the potential nitrogen $(\mathrm{N})$ losses on an andisoil of Southern Chile with different fertilisers. The treatments tested were: fish slurry (FS), dairy slurry (DS), potassium nitrate (IF) and a control treatment (C), with no N addition. An equivalent amount of $150 \mathrm{~kg}$ of total $\mathrm{N} \mathrm{ha}^{-1}$ was applied to each lysimeter and then the equivalent to $1260 \mathrm{~mm}$ of rainfall was irrigated over a 90 days period. Leachate samples were analysed for nitrate, nitrite, ammonia and organic $\mathrm{N}$ (No). Total $\mathrm{N}$ losses were calculated as the product between drainage and the respective $\mathrm{N}$ concentration in the leachates. Lowest $\mathrm{N}$ losses were obtained in the control and FS treatments $\left(66 \mathrm{~kg} \mathrm{~N} \mathrm{ha}^{-1}\right)$ and the greatest amount was obtained in the IF treatment $\left(261 \mathrm{~kg} \mathrm{~N} \mathrm{ha}^{-1}\right)$. Nitrogen was mainly lost as nitrate and No (each was $49 \%$ of the total $\mathrm{N}$ losses). High soil organic matter of andisoils can be more relevant than fertiliser for $\mathrm{N}$ leaching losses.
\end{abstract}

Palabras claves: Lodo de pescado, purines de lechería, fertilizante inorgánico, calidad de agua 


\section{RESUMEN}

Un experimento con lisímetros intactos se llevó a cabo para medir el potencial de pérdida de nitrógeno $(\mathrm{N})$ en un andisol del sur de Chile con diferentes fertilizantes. Los tratamientos evaluados fueron purín de pescado (FS), purín de lechería (DS), nitrato de potasio (IF) y un tratamiento control (C), sin adición de N. Se aplicó una dosis equivalente a $150 \mathrm{~kg} \mathrm{ha}^{-1}$ de $\mathrm{N}$ total a cada lisímetro y luego estos fueron regados con el equivalente a $1260 \mathrm{~mm}$ de lluvia distribuida en un periodo de 90 días. Las muestras de lixiviado fueron analizadas para nitrato, nitrito, amonio y $\mathrm{N}$ orgánico (No). Las pérdidas totales de $\mathrm{N}$ fueron calculadas como el producto del drenaje colectado y su respectiva concentración de $\mathrm{N}$ en la muestra. Las pérdidas más bajas de $\mathrm{N}$ se obtuvieron en el tratamiento control y en el tratamiento FS ( $\left.66 \mathrm{~kg} \mathrm{~N} \mathrm{ha}^{-1}\right)$, y las pérdidas más altas se obtuvieron el tratamiento IF (261 $\mathrm{kg} \mathrm{N} \mathrm{ha}^{-1}$ ). El nitrógeno fue perdido principalmente como nitrato y como No (cada uno representó el $49 \%$ del total de las pérdidas). El alto contenido de materia orgánica de un andisol puede ser más relevante para las pérdidas de $\mathrm{N}$ por lixiviación que el tipo de fertilizante utilizado.

\section{INTRODUCTION}

The Lake Region of southern Chile (39 to $44 \mathrm{~S}$ and 71 to $74 \mathrm{~W}$ ), has suitable climatic conditions and soil types for cattle production. Consequently, $56 \%$ of the national cattle herd is concentrated in this maritime temperate climatic region, grazed on natural and improved pastures. These cattle produce $60 \%$ of the country's milk and $45 \%$ of the meat (INE, 1997).

Volcanic soils are widespread in southern Chile accounting for $60 \%$ of the nation's arable land. They are characterised by low nutrient availability, high phosphorus (P) fixation capacity, high organic matter (OM) content and a $\mathrm{pH}$-dependent cation exchange capacity (Escudey et al., 2001).

In developed countries the environmental impact of livestock systems has been widely studied because of the important role of this activity on water, soil and air pollution (Jarvis and Oenema, 2000). It has been estimated that agriculture contributes $37 \%$ to $82 \%$ of the $\mathrm{N}$ input into surface waters of Western Europe (Isermann, 1990). International literature commonly reports information on $\mathrm{N}$ leaching losses after inorganic fertiliser addition (i.e. Di et al., 1998) or different animal manure applications (i.e., Misselbrook et al., 1996), but no published information exists on fish sludge effect on $\mathrm{N}$ losses.

Despite the importance of livestock production in southern Chile and the fact that $\mathrm{N}$ is a strategic nutrient for grassland production, there is little information about N leaching losses (i.e. Salazar, 2002; Nissen and Daroch, 1991). Most of the studies carried out worldwide have focussed on nitrate leaching (i.e. Misselbrook et al., 1996); however, recent studies have shown organic $\mathrm{N}$ leaching occurring from soils (i.e., Hawkins and Scholefield, 2000; Murphy et al., 2000), with no published information about it under Chilean conditions.

The objective of this study was to assess $\mathrm{N}$ leaching losses on an andisoil of Southern Chile with the application of different types of fertilizer.

\section{MATERIALS AND METHODS}

\section{Lysimeter and experimental design}

An intact lysimeters study was carried out at the Remehue Research Centre (INIA), in southern Chile $\left(40^{\circ} 55^{\prime} \mathrm{S}, 73^{\circ} 08^{\prime} \mathrm{W}\right)$, 
between April and December of 2003 with four treatments distributed on a randomised design with three replicates. The treatments tested were a control (C) with no fertiliser addition, lake fish sludge (FS), dairy slurry (DS) and an inorganic source (IF) $\left(\mathrm{KNO}_{3}\right.$; $15 \% \mathrm{~N}, 14 \% \mathrm{~K}_{2} \mathrm{O}$ ). The fertilised treatments received an equivalent to $150 \mathrm{~kg}$ total $\mathrm{N} \mathrm{ha}^{-1}$.

Lake fish sludge was collected from the bottom of the fish farming cages in the area of the study in October 2002 and was kept at room temperature until the time of application. Dairy slurry was collected a week before the experiment started, from the dairy unit at the Remehue Research Centre, and kept at $5-7^{\circ} \mathrm{C}$ until required. At the moment of the application the dry matter content, $\mathrm{pH}$, total $\mathrm{N}$ concentration and ammonium $\mathrm{N}$ concentration of the FS and DS were $13.7 \%, 7.3,0.09 \%$ and $0.02 \%$ for FS and $6.8 \%, 7.4,0.09 \%$ and $0.06 \%$ for DS, respectively.

The soil used in this experiment belongs to the Osorno soil series (Typic Hapludands; CIREN 2003), being characterised by more than $1 \mathrm{~m}$ depth and free drainage. The soil was collected from a site with permanent grassland over the last 20 years, which has not been used for grazing for a year and had received no fertiliser application.

Lysimeters were collected manually at 0.60 m depth $\left(04^{\text {th }}\right.$ of March 2003) in PVC tubes type 10 with $200 \mathrm{~mm}$ of external diameter and $190 \mathrm{~mm}$ of internal diameter. A perforated lid (holes of $5 \mathrm{~mm}$ diameter) was placed at the bottom of each lysimeter to allow drainage. This lid was covered in the inside by one filter (nylon net ASTM 18-1000) and one membrane (nylon net ASTM No120/125), to avoid contamination of leachate samples. Expandable sponge was used at the soil surface level to avoid preferential flow by the lysimeters' wall. Lysimeters were carefully transported to the laboratory after collection and kept under control conditions. Prior to the experiment the grass cover was cut to surface level (10 $\mathrm{mm}$ residue). After this, grass did not grow enough to allow ulterior cuts, so that no $\mathrm{N}$ uptake was observed during the experimental period.

The fertiliser application was carried out the $6^{\text {th }}$ of June 2003. Rainfall started the following day with the use of distilled water. The total amount of rainfall applied was of $1260 \mathrm{~mm}$, distributed over a 12 weeks period, so that the soil was permanently saturated. This amount of rainfall is the average for the last 28 years in the area of study. Daily evapotranspiration data in the laboratory was determined with the use of an evaporation tray. Leachates samples were collected daily from the bottom of the lysimeters in polyethylene bottles $(150 \mathrm{ml})$ which were rinsed twice before final collection. Bottles were kept at $5-7^{\circ} \mathrm{C}$ until analysis for the different $\mathrm{N}$ forms.

\section{Chemical analysis and evaluations}

A soil chemical characterisation was made (0-20, 20-40 and 40-60 cm) before the experiment started (Olsen $\mathrm{P}$, water $\mathrm{pH}$, cation exchange capacity) according to Sadzawka (1990). The bulk density of each soil layer was determined by the cylinder method (Rowell, 1997).

At the end of the experimental period the soil of the lysimeters was samples and analysed for available $\mathrm{N}\left(\mathrm{N}-\mathrm{NH}_{4}{ }^{+}\right.$and $\mathrm{N}-$ $\mathrm{NO}_{3}^{-}$) at 0-20, 20-40 and 40-60 $\mathrm{cm}$ depth according to Sadzawka (1990). Also, soil from the $0-20 \mathrm{~cm}$ layer was used to determine the amount of potential $\mathrm{N}$ mineralization, according to Lober and Reeder (1993).

Leachate samples were analysed for ammonium-N $\left(\mathrm{NH}_{4}^{+}-\mathrm{N}\right)$, nitrate-N $\left(\mathrm{NO}_{3}-\mathrm{N}\right)$, nitrite- $\mathrm{N}\left(\mathrm{NO}_{2}-\mathrm{N}\right)$ and dissolved organic N (No). Nitrate and ammonium concentrations were determined in a Skalar autoanalyser. Nitrate was measured using the salicylic acid method (Robarge et al., 1983), and ammonium was determined 
through the indophenol methodology (Mulvaney, 1996). Nitrite was determined by the colorimetric method with $\mathrm{Cd}$ and $\mathrm{Cu}$ reductive column and No with the macroKjeldahl method (Bremmer and Mulvaney, 1982). Because of the low nitrite concentrations detected during the first weeks of measurements, this was stopped at the end of the first month of sampling. Organic $\mathrm{N}$ was measured during the first month of sampling and, because the high correlation with nitrate concentration in the samples, this relationship was used to predict No in the following samples. The total amount of $\mathrm{N}$ lost $\left(\mathrm{kg} \mathrm{N} \mathrm{ha}^{-1} \mathrm{yr}^{-1}\right)$ was estimated as the product between the daily amount of drainage and the concentration of each of the different $\mathrm{N}$ forms in those samples. Because the amount of rainfall irrigated during the experiment corresponded to the average of the total annual rainfall registered in the area and because this was irrigated over a three months period, $\mathrm{N}$ losses reported in this study are the estimated potential $\mathrm{N}$ losses for the area.

Analysis of Variance (ANOVA) was used to compare the overall average concentrations and total loads for each $\mathrm{N}$ form and treatment. It was also used to compare differences in the available $\mathrm{N}$ concentration in the soil at the end of the experimental period between treatments and soil layers and differences between treatments in the potentially available $\mathrm{N}$ in

Table 1: Initial chemical characterisation of the soil used in the intact lysimeter experiment at three different dephts $(\mathrm{cm})$. Osornosoil series, 20 $0^{\text {th }}$ March 2003( \pm sem, n=3)

Cuadro 1: Caracterización inicial del suelo utilizando en el experimento con lisímetros intactos a tres profundidades (cm). Serie de suelo Osorno, 20 de Marzo 2003( \pm esm, n=3)

\begin{tabular}{|c|c|c|c|}
\hline \multirow[b]{2}{*}{ Characteristic } & \multicolumn{3}{|c|}{ Soil layer $(\mathrm{cm})$} \\
\hline & $0-20$ & $20-40$ & $40-60$ \\
\hline Olsen $\mathrm{P}\left(\mathrm{mg} \mathrm{kg}^{-1}\right)$ & $3 \pm 0.4 \mathrm{a}$ & $1 \pm 0.1 b$ & $2 \pm 0.2 b$ \\
\hline pH (water) & $5.8 \pm 0.02 b$ & $6.0 \pm 0.08 \mathrm{a}$ & $6.2 \pm 0.01 \mathrm{a}$ \\
\hline Cation exchange capacity $\left(\mathrm{mg} \mathrm{kg}^{-1}\right)$ & $2.9 \pm 0.56 \mathrm{a}$ & $0.5 \pm 0.02 b$ & $0.8 \pm 0.07 b$ \\
\hline Available $\mathrm{Al}\left(\mathrm{mg} \mathrm{kg}^{-1}\right)$ & $0.2 \pm 0.02 \mathrm{a}$ & $0.0 \pm 0.002 \mathrm{~b}$ & $0.0 \pm 0.001 \mathrm{~b}$ \\
\hline $\mathrm{NH}_{4}{ }^{+}-\mathrm{N}\left(\mathrm{mg} \mathrm{kg}^{-1}\right)$ & $5 \pm 0.2 \mathrm{a}$ & $4 \pm 1.0 \mathrm{a}$ & $4 \pm 0.4 \mathrm{a}$ \\
\hline $\mathrm{NO}_{3}^{-}-\mathrm{N}\left(\mathrm{mg} \mathrm{kg}^{-1}\right)$ & $3 \pm 0.5 \mathrm{a}$ & $1 \pm 0.6 \mathrm{~b}$ & $1 \pm 0.6 \mathrm{~b}$ \\
\hline Organic matter $(\%)$ & $18 \pm 0.1 \mathrm{a}$ & $17 \pm 0.4 \mathrm{a}$ & $16 \pm 0.7 \mathrm{a}$ \\
\hline Bulk density $\left(\mathrm{g} \mathrm{cm}^{-3}\right)$ & $0.6 \pm 0.02 \mathrm{a}$ & $0.5 \pm 0.01 \mathrm{a}$ & $0.5 \pm 0.02 \mathrm{a}$ \\
\hline
\end{tabular}

Different letters in columns indicate significant differences $(\mathrm{P} \leq 0,05)$. \pm Standard error of the mean 
the soil after the mineralization test. SAS was used as statistical package.

\section{RESULTS}

\section{Soil}

Soil results showed that initial Olsen $\mathrm{P}$ concentrations were less than $5 \mathrm{mg} \mathrm{kg}^{-1}$ and that the bulk density of the soil did not changed with depth $(\mathrm{P}>0.05$; Table 1$)$.

\section{Lysimeters}

The evapotranspiration was $0.1+0.0004 \mathrm{~mm}$ day- 1 on average, which represented a $0.7 \%$ of the rainfall applied daily. The average drainage collected from each replicate was of $35 \mathrm{~L}$, with no significant differences between treatments $(P>0.05)$, this value represented $98.4 \%$ of the total amount of rainfall applied. The pattern of drainage was not different between treatments $(\mathrm{P}>0.05)$.

Table 2: Average $\mathrm{N}$ leachates concentation $\left(\mathrm{ml} \mathrm{L}^{-1}\right)$ and potential $\mathrm{N}$ losses $\left(\mathrm{kg} \mathrm{ha}^{-1}\right)$ in different $\mathrm{N}$ forms after the application of $150 \mathrm{~kg}$. total $\mathrm{N}$ as inorganic or organic fertilizer to intact lysimeters. Total rainfall applied was equivalent to $12600 \mathrm{~mm}$. Experimental period of 90 days $( \pm$ sem, $n=3$ )

Cuadro 2: Concentración promedio de $\mathrm{N}$ en lixiviados $\left(\mathrm{ml} \mathrm{L}^{-1}\right)$ y pérdidas potenciales de $\mathrm{N}\left(\mathrm{kg} \mathrm{ha}^{-1}\right)$ para diferentes formas de $\mathrm{N}$ después de la aplicación de $150 \mathrm{~kg}$. de $\mathrm{N}$ total como fertilizante inorgánico y orgánico a lisímetros intactos. Total de lluvia aplicada equivalente a $12600 \mathrm{~mm}$. Período experimental de 90 días ( \pm esm, n=3)

\begin{tabular}{|c|c|c|c|c|c|c|}
\hline \multirow[t]{2}{*}{ Fertilizer } & \multicolumn{6}{|c|}{$\mathrm{N}$ concentration $\left(\mathrm{mg} \mathrm{L}^{-1}\right)$} \\
\hline & $\mathrm{N}-\mathrm{NO}_{3}^{-}$ & No & \multicolumn{2}{|c|}{$\mathrm{N}-\mathrm{NH}_{4}{ }^{+}$} & \multicolumn{2}{|c|}{$\mathrm{N}-\mathrm{NO}_{2}^{-}$} \\
\hline Control & $1.2 \pm 0.32 \mathrm{c}$ & $1.2 \pm 0.32 \mathrm{c}$ & \multicolumn{2}{|c|}{$0.02 \pm 0.004 \mathrm{a}$} & \multicolumn{2}{|c|}{$0.005 \pm 0.0026 \mathrm{a}$} \\
\hline Dairy slurry & $2.3 \pm 0.65 b$ & $2.3 \pm 0.65 b$ & \multicolumn{2}{|c|}{$0.02 \pm 0.004 \mathrm{a}$} & \multicolumn{2}{|c|}{$0.005 \pm 0.0018 \mathrm{a}$} \\
\hline Fish Sludge & $1.3 \pm 0.29 \mathrm{c}$ & $1.3 \pm 0.29 \mathrm{c}$ & \multicolumn{2}{|c|}{$0.01 \pm 0.004 \mathrm{a}$} & \multicolumn{2}{|c|}{$0.009 \pm 0.0068 \mathrm{a}$} \\
\hline \multirow[t]{3}{*}{ Inorganic fertiliser } & $4.4 \pm 1.22 \mathrm{a}$ & $4.4 \pm 1.22 \mathrm{a}$ & \multicolumn{2}{|c|}{$0.02 \pm 0.005 \mathrm{a}$} & \multicolumn{2}{|c|}{$0.004 \pm 0.0019 \mathrm{a}$} \\
\hline & \multicolumn{6}{|c|}{ Losses $\left(\mathrm{kg} \mathrm{ha}^{-1}\right)$} \\
\hline & $\mathrm{N}-\mathrm{NO}_{3}{ }^{-}$ & No & $\mathrm{N}-\mathrm{NH}_{4}{ }^{+}$ & & $-\mathrm{NO}_{2}^{-}$ & Total \\
\hline Control & $33 \pm 8.6 c$ & $33 \pm 8.6 \mathrm{c}$ & $0.2 \pm 0.05 \mathrm{a}$ & 0.02 & $\pm 0.009 \mathrm{a}$ & 66 \\
\hline Dairy slurry & $67 \pm 13.4 b$ & $67 \pm 13.4 b$ & $0.3 \pm 0.07 \mathrm{a}$ & 0.01 & $\pm 0.004 \mathrm{a}$ & 134 \\
\hline Fish Sludge & $33 \pm 7.3 \mathrm{c}$ & $33 \pm 7.3 \mathrm{c}$ & $0.2 \pm 0.05 \mathrm{a}$ & 0.01 & $\pm 0.006 \mathrm{a}$ & 66 \\
\hline Inorganic fertiliser & $131 \pm 28.8 \mathrm{a}$ & $131 \pm 28.8 \mathrm{a}$ & $0.3 \pm 0.08 \mathrm{a}$ & 0.01 & $\pm 0.005 \mathrm{a}$ & 262 \\
\hline
\end{tabular}


Low $\mathrm{NH}_{4}{ }^{+}-\mathrm{N}$ and $\mathrm{NO}_{2}-\mathrm{N}$ concentrations were measured in the leachates, average for the experimental period were less than 0.05 and $0.009 \mathrm{mg} \mathrm{L}^{-1}$, respectively (Table 2), with no differences between treatments ( $P>0.05$; Table 2). The contribution of these $\mathrm{N}$ forms to total $\mathrm{N}$ losses was negligible. The highest $\mathrm{N}$ concentrations in the samples were those of $\mathrm{NO}_{3}^{-}$and No, being both significantly different between treatments $(\mathrm{P} \leq 0.05$; Table 2).

Total $\mathrm{N}$ losses varied between 66 and $261 \mathrm{~kg} \mathrm{~N} \mathrm{ha}^{-1}$. Lower losses were estimated for the $\mathrm{C}$ and $\mathrm{FS}$ treatments and the highest loss was measured in the IF treatment $(\mathrm{P} \leq 0.05$; Table 2).

The pattern of the $\mathrm{NO}_{3}{ }^{-}$concentration in the leachates was different between treatments over time $(\mathrm{P} \leq 0.05)$, with greater rates and peak in the IF treatment (Figure $1)$.

During the first month of sampling, when No was analysed in leachate samples, average $\mathrm{N}$ concentration was similar between treatments with $0.58,0.61,0.55$ and 0.68 $\mathrm{mg} \mathrm{L}^{-1}$ for the C, FS, DS and IF treatments ( $\mathrm{P}>0.05)$, respectively, being closely related to $\mathrm{NO}_{3}{ }^{-}$in sample concentrations at that time $\left(\mathrm{Y}=1.00+0.029 ; \mathrm{R}^{2}=0.99\right)$, as indicated in the materials and methods section. Because of this, this correlation was used to model No concentration for the remaining of the experimental period. Over the first month, total No losses measured were equivalent to $0.22,0.24,0.22$ and $0.27 \mathrm{~kg} \mathrm{No} \mathrm{ha}^{-1}$ ( $\mathrm{P}>0.05)$.

\section{Residual N}

Available $\mathrm{N}$ concentration in the soil at the end of the experimental period was different between treatments and soil layers, being greater in the $0-20 \mathrm{~cm}$ layer and in the FS treatment $(\mathrm{P} \leq 0.05$; Figure 2$)$. No differences were found between treatments for the mineralization test carried out at the end of the experiment. Values varied between 13 and $17 \mathrm{mg} \mathrm{N} \mathrm{g} \mathrm{soil}^{-1}(\mathrm{P}>0.05)$.

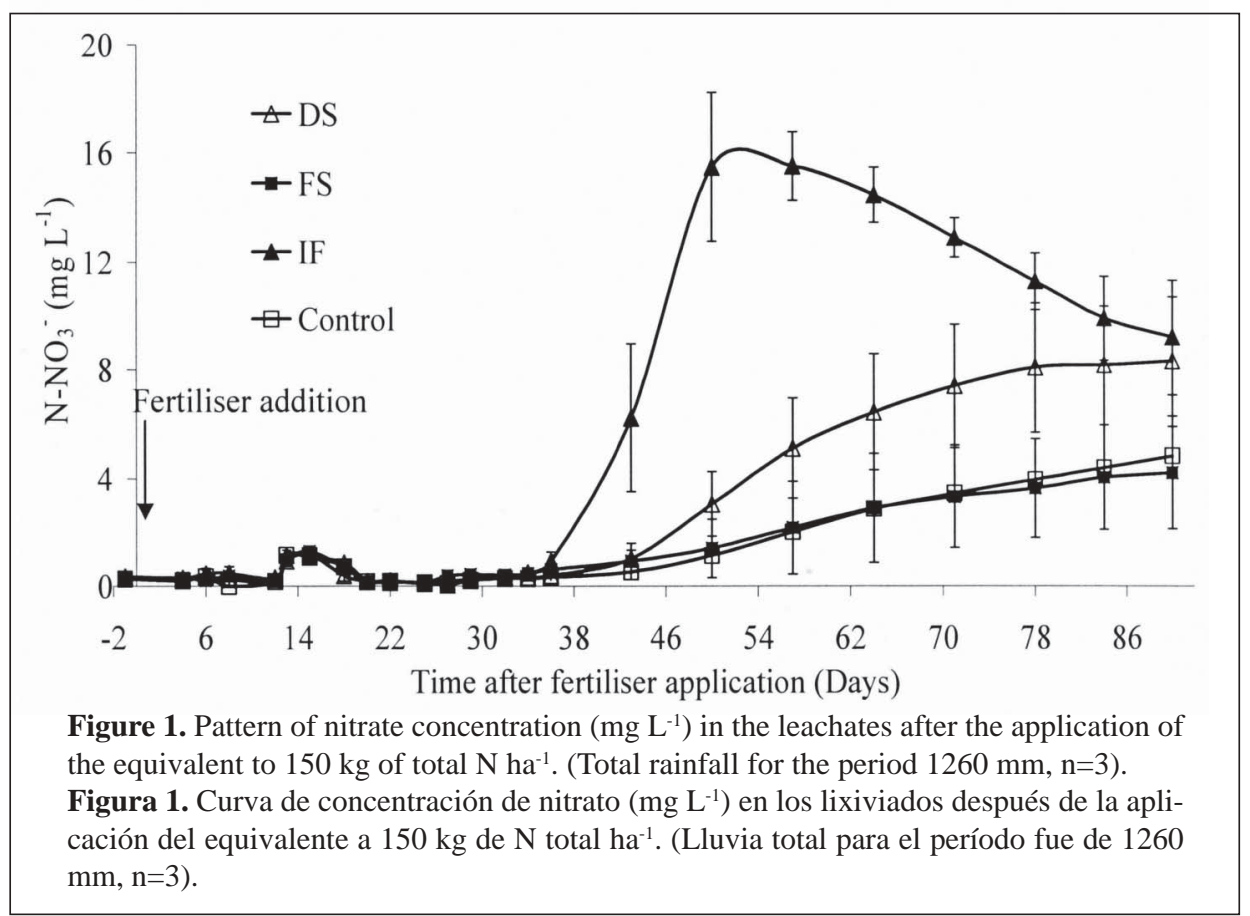




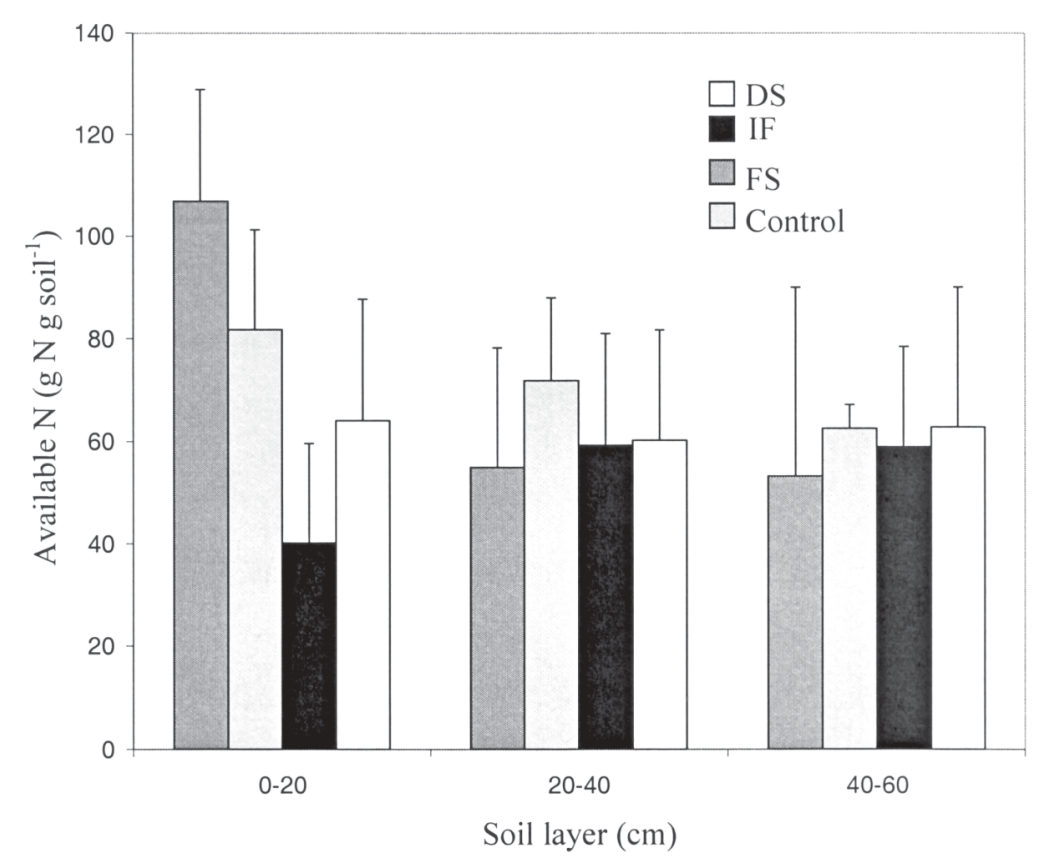

Figure 2. Available nitrogen ( $\left.\mathrm{g} \mathrm{N} \mathrm{g} \mathrm{dry} \mathrm{soil}{ }^{-1}\right)$ at the end of the experimental period per treatment at each soil layer $(\mathrm{n}=3)$.

Figura 2. Nitrógeno disponible ( $\mathrm{g} \mathrm{N}$ g suelo $\mathrm{seco}^{-1}$ ) por tratamiento y para cada estrata de suelo al final del período experimental $(n=3)$.

\section{DISCUSSION}

The saturation point reached by the soil after the initial irrigations resulted in no significant differences in the amount of total drainage between treatments or lysimeters, so that differences in the total amount of $\mathrm{N}$ lost between treatments can be attributed to the particular characteristics of the fertilisers used and not to changes in the hydrology of the soil.

Nitrite and ammonium concentrations were negligible, so that these forms were not relevant for $\mathrm{N}$ losses from an andisoil under cut grass, in contrast of grazed areas, in agreement with Alfaro et al. (2005).

Greater average $\mathrm{N}$ concentrations were those of nitrate and No, but only average daily $\mathrm{NO}_{3}{ }^{-}$concentration at the peak from the IF treatment was greater than the $11.3 \mathrm{mg} \mathrm{L}^{-1}$ established as maximum recommendable for drinking water (i.e. European Union, 91/676/ EEC), implying a low risk for underground water pollution in grazed areas of southern Chile. Average $\mathrm{N}$ fertiliser application in these areas is commonly no more than $45 \mathrm{~kg} \mathrm{~N}$ ha ${ }^{1}$ per time (Alfaro and Salazar, 2005), so that the widespread risk of underground water pollution in the area is low.

Because of differences in the concentration of the different $\mathrm{N}$ forms in the samples collected, $\mathrm{N}$ was lost mainly as nitrate and No (49\% of total $\mathrm{N}$ losses each).

The FS and $\mathrm{C}$ treatments had the same pattern of $\mathrm{N}$ lost as nitrate, so that the low $\mathrm{N}$ availability of this fertiliser resulted in a similar behaviour to that of the soil organic matter (OM), with no $\mathrm{N}$ addition. The high OM of the soil (Table 1), which suggests a high soil biomass activity, could explain the 
high contribution of organic $\mathrm{N}$ to total $\mathrm{N}$ losses in all treatments (49\%), in agreement with Jarvis (2002) and Murphy et al. (2000). This implies the need to consider organic $\mathrm{N}$ forms when studying the potential effect of fertiliser treatments on $\mathrm{N}$ leaching losses, given the high OM content of Chilean soils. These results are the first published data reported in the national literature.

Even though the legislation considers this form as part of the total $\mathrm{N}$ fraction, water pollution studies do not consider the presence and reactivity of this $\mathrm{N}$ form when assessing $\mathrm{N}$ leaching effects. This aspect can be relevant for water eutrophication as it is thought that this form of $\mathrm{N}$ is rapidly available for algae grow (Murphy et al., 2000). Beside No, nitrate was the other main $\mathrm{N}$ form for $\mathrm{N}$ loss, in agreement with Alfaro et al. (2005) and Ledgard et al. (1999).

Total $\mathrm{N}$ losses were related to the type of fertiliser used, with greater losses from the inorganic source and lower losses from the organically fertilised treatments. This effect is also supported by the lower available $\mathrm{N}$ concentration found at the end of the experimental period in the IF treatment in the $0-20$ $\mathrm{cm}$ layer, and the greater available $\mathrm{N}$ in the organically fertilised treatments at this depth.

Nitrate losses were greater than those reported by Ledgard et al. (1999) in dairy grazing systems in New Zealand, with a similar andisoil to that used in the present study, both with no $\mathrm{N}$ addition and the addition of $200 \mathrm{~kg} \mathrm{~N} \mathrm{ha}^{-1}$ (20-74 and $101 \mathrm{~kg} \mathrm{ha}^{-1} \mathrm{yr}^{-1}$, respectively). Losses were also greater than those reported by Jaramillo et al. (2005) for grazed grass in the same area with the addition of $67.5 \mathrm{~kg} \mathrm{~N}^{-1}$ (11-30 kg ha' $\left.\mathrm{yr}^{-1}\right)$. This was probably because in the present experiment the rainfall applied was equivalent to the annual average rainfall in the area and because this was applied over a short period of time (three months). This was done to establish the potential maximum $\mathrm{N}$ loss under soil and grassland conditions of the area. High $\mathrm{N}$ losses from the control treatment could be related to the high OM of the soil, as discussed previously.

Results of the present study showed that No form represented $49 \%$ of the total $\mathrm{N}$ lost by leaching, in agreement with Jarvis (2002) who found that in grassland systems with low $\mathrm{N}$ inputs, as is the case of the present study, No can be up to $50 \%$ of the total $\mathrm{N}$ lost. The amount of No lost by leaching measured in this experiment agrees with results found in England on permanent pastures receiving up to $200 \mathrm{~kg} \mathrm{~N} \mathrm{ha}^{-1} \mathrm{yr}^{-1}$ (89 and $272 \mathrm{~kg} \mathrm{~N} \mathrm{ha}^{-1} \mathrm{yr}^{-}$ ${ }^{1}$; Hawkins and Scholefield, 2000), probably because in the present study rainfall was concentrated after $\mathrm{N}$ addition as fertiliser.

The high $\mathrm{OM}$ of the soil could have masked the effect of the fertilisers added, because no differences were found between treatments in the mineralization test carried out at the end of the experimental period. This suggests that in andisoils with high OM content, the soil biomass and the natural soil $\mathrm{N}$ mineralization processes could be a key factor in controlling the total $\mathrm{N}$ losses by leaching, being more relevant than the addition of fertiliser.

This study has presented novel data about the quantity and types of $\mathrm{N}$ loss from a volcanic ash soil in southern Chile. Results showed that soil organic matter can be the main factor controlling $\mathrm{N}$ flows from this soil to waters, being more relevant that fertilizer, but further studies are required to fully understand $\mathrm{N}$ cycling in this soil type.

\section{CONCLUSIONS}

Total $\mathrm{N}$ losses were high (66-262 $\mathrm{kg} \mathrm{N} \mathrm{ha}^{-1}$ ), probably because the high amount of rainfall applied to the lysimeters $(1260 \mathrm{~mm})$ and the high soil organic matter content.

Total losses decreased in the following order IF $>$ DS $>$ FS $=\mathrm{C}$. The high $\mathrm{N}$ losses from the control treatment could be related to the soil OM content and biomass activity.

Differences in the amount of total $\mathrm{N}$ lost by leaching resulted in differences in the 
amount of available $\mathrm{N}$ found at the end of the experimental period in the $0-20 \mathrm{~cm}$ soil layer, but did not changed the potential $\mathrm{N}$ mineralization test results.

The high $\mathrm{OM}$ of the soil could have masked the effect of the fertilisers added. This suggests that in andisoils with high OM content, the soil biomass and the natural soil $\mathrm{N}$ mineralization processes could be a key factor in controlling the total $\mathrm{N}$ losses by leaching.

Organic $\mathrm{N}$ and nitrate were the main forms of $\mathrm{N}$ loss (49\% each). The high organic matter of the soil could explain the high contribution of organic $\mathrm{N}$ to total $\mathrm{N}$ losses in all treatments. Because the important contribution of No to total $\mathrm{N}$ losses, this $\mathrm{N}$ form should be considered in future leaching studies.

\section{ACKNOWLEDGEMENTS}

This research was funded by FONDEF (Grant D01I1113).

\section{REFERENCES}

ALFARO, M., SALAZAR, F. 2005. Ganadería y contaminación difusa, implicancias para el sur de Chile. Agricultura Técnica 65: 330-340.

ALFARO, M.; SALAZAR, F., IRAIRA, S., TEUBER, N., RAMÍREZ, L. 2005. Nitrogen runoff and leaching losses under two different stocking rates on beef production systems of southern Chile. Gayana Botanica 62:130-138. BREMMER, J.M., MULVANEY, C.S. 1982. Total nitrogen, in A.L. Page: Methods of soil analysis: Chemical and microbiological properties. American Society of Agronomy Inc. Madison Wisconsin USA, p. 595-624.

CIREN, 2003. Descripciones de suelos, materiales y símbolos, estudio agrológico X Región Vol. II, Centro de Información de Recursos Naturales Santiago Chile.
DI, H.J., CAMERON, K.C., MOORE, S., SMITH, N.P. 1998. Nitrate leaching and pasture yields following the application of dairy shed effluent or ammonium fertilizer under spray or flood irrigation: results of a lysimeter study. Soil Use and Management 14: 209-214

ESCUDEY, M., GALINDO, G., FÖRSTER, J., BRICEÑO, M., DIAZ, P., CHANG, A. 2001. Chemical forms of phosphorus of volcanic ashderived soils in Chile. Communication in Soil Science and Plant Analysis 32: 601-616.

HAWKINS, J., SCHOLEFIELD, D. 2000. Leaching of dissolved organic $\mathrm{N}$ from grass-white clover pasture in SW England, in K, Søegaard, C. Ohlsson, J. Sehested, N. J. Hutchings, T. Kristensen: Grassland farming, balancing environmental and economic demands. Proceedings of the 18th General Meeting of the European Grassland Federation, Denmark. Grassland Science in Europe, p: 378-380.

INE, 1997. Resultados preliminares VI Censo Agropecuario. Instituto Nacional de Estadísticas, Impresos Universitarios SA Santiago Chile.

ISERMANN, K. 1990. Share of agriculture in nitrogen and phosphorus emissions into the surface waters of Western Europe against the background of their eutrophication. Fertilizer Research 26: 253-269.

JARAMILLO, J., SALAZAR, F., ALFARO, M., PINOCHET, D., RAMÍREZ, L. 2005. Efecto de la carga animal sobre la lixiviación de nitrógeno en una pradera permanente de producción bovina de carne, in L. Lopez y N. Sepúlveda: Libro de Resúmenes de la XXX Reunión Anual de la Sociedad Chilena de ProducciónAnimal (SOCHIPA), SOCHIPA Temuco Chile, p.191-192. 
JARVIS, S.C. 2002. Environmental impacts of cattle housing and grazing, in $\mathrm{M}$. Kaske, H. Scholz and M. Höltershinken: Recent developments and perspectives in bovine medicine. Keynotes lectures of the 22nd World Buiatrics Congress. World Buiatrics Association Germany, p. 10-23.

JARVIS, S.C., OENEMA, O. 2000. Measuring and monitoring nitrogen and phosphorus flows and losses in grassland systems, in L't. Mannetje and R.M. Jones: Field and Laboratory Methods for Grassland and Animal Production Research, CAB International Cambridge UK, p. 305-325.

LEDGARD, S.F., PENNO, J.W., SPROSEN, M.S. 1999. Nitrogen inputs and losses from clover/grass pastures grazed by dairy cows, as affected by nitrogen fertilizer application. Journal of Agricultural Science, Cambridge 132: 215-225.

LOBER, R.W., REEDER, J.D. 1993. Modified waterlogged incubation method for assessing nitrogen mineralization in soils and soil aggregates. Soil Science Society of America Journal 57: 400-403

MISSELBROOK, T.H., LAWS, J.A., PAIN, B.F. 1996. Surface applications and shallow injection of cattle slurry on grassland: nitrogen losses, herbage yields and nitrogen recoveries. Grass and Forage Science 51: 270-277

MULVANEY, C.S. 1996. Nitrogeninorganic forms, in D.L. Sparks and J.M. Bartels: Methods of soil
Analysis: Chemical Methods. Soil Science Society of America, American Society of Agronomy. Madison Wisconsin USA, p.1152-1155.

MURPHY, D.V., MACDONALD, A.J., STOCKDALE, E.A., GOULDING, K.W.T., FORTUNE, S., GAUNT, J.L., POULTON, P.R., WAKEFIELD, J.A., WEBSTER, C.O., WILMER, W.S. 2000. Soluble organic nitrogen on agricultural soils. Biology and Fertility of Soils 30: 374-387.

NISSEN, J., DAROCH, R. 1991. Efecto del riego sobre la lixiviación de nitrógeno en una pradera de rotación corta para la zona agroclimática de Valdivia. Agro Sur 19: 124-129.

ROBARGE, W.P., EDWARDS, A., JOHNSON, B. 1983. Water and waste water analysis for nitrate via nitration of salicylic acid. Communications in Soil Science and Plant Analysis 14: 1207-1215.

ROWELL, D.L. 1997. Soil Science, methods and applications. Longman Group UK Ltd. Harlow England.

SADZAWKA, A. 1990. Métodos de análisis de suelos. INIA La Platina No 16 Instituto de Investigaciones Agropecuarias Ministerio de Agricultura Santiago Chile.

SALAZAR, M.A. 2002. Lixiviación de nitrógeno proveniente de urea, en el periodo de mayor crecimiento de una pradera de Lolium multiflorum cv. Tama. Estudio en lisímetros. Tesis Ingeniero Agrónomo, Universidad de La Frontera, Chile. 71p. 